\title{
BAHAYA PESTISIDA SINTETIK (SOSIALISASI DAN PELATIHAN BAGI WANITA KAUM IBU DESA KOKA KECAMATAN TOMBULU KABUPATEN MINAHASA)
}

\author{
Marina Flora Oktavine Singkoh ${ }^{1 *}$, Deidy Y Katilii \\ ${ }^{1}$ Jurusan Biologi, Fakultas Matematika Dan Ilmu Pengetahuan Alam \\ Universitas Sam Ratulangi \\ *Penulis Korespondensi, Marina Flora Oktavine Singkoh Jurusan Biologi FMIPA Universitas Sam \\ Ratulangi Manado 95115. Email: marinasingkoh@unsrat.ac.id
}

\begin{abstract}
ABSTRAK
Kelemahan umum yang dijumpai dikalangan petani dalam meningkatkan produksi pertanian dan dalam menanggulangi hama dan penyakit tumbuhan adalah kurangnya pengetahuan mereka tentang dampak negatif dari residu pestisida yang dapat menimbulkan pencemaran lingkungan, terbunuhnya musuh-musuh alami, terjadinya resistensi dan resurgensi hama, timbulnya residu pada komoditi hasil pertanian tersebut, dan berbahaya bagi manusia lingkungan serta manusia. Tujuan dan target khusus yang ingin dicapai pada kegiatan PKM ini adalah peningkatan pengetahuan dan ketrampilan petani dalam penggunaan pestisida sintetis secara terkendali untuk mengurangi tingkat keracunan yang diakibatkannya dan peningkatan kesadaran lingkungan hidup bagi masyarakat di Desa Koka Kecamatan Tombulu Kabupaten Minahasa dari dampak samping yang ditimbulkan oleh pestisida bagi lingkungan dan kesehatan manusia. Untuk mengatasi permasalahan kurangnya pengetahuan petani tentang penggunaan pestisida sintetik dan dampak samping yang ditimbulkannya, akan digunakan metode penyuluhan dan pelatihan bahaya penggunaan pestisida sintetik terhadap lingkungan dan kesehatan manusia. Hasil kegiatan PKM ini yaitu terjadi peningkatan pemahaman peserta akan materi sosialisasi dan pelatihan bahaya penggunaan pestisida sintetik pada saat sebelum kegiatan PKM dilaksanakan dan sesudah kegiatan dilaksanakan ditandai dengan jumlah prosentasi nilai pretest pada interval nilai 51-100 sebesar 0,00\% (tidak ada peserta) terjadi peningkatan pada postest sebesar $91.89 \%$ (34 orang). Pada pretest tidak ada peserta yang mendapatkan nilai tertinggi pada interval nilai 91-100 $(0,00 \%)$ tetapi pada postest terdapat 1 orang dengan prosentase sebesar 2,71\%. Hasil praktek menunjukkan bahwa kriteria tertinggi pada aspek ke 3 (motivasi peserta menindaklanjuti semua petunjuk sesuai pelatihan ) dengan kriteria sangat baik (25 peserta), sedangkan kriteria terendah pada aspek ke 2 (kesesuian materi dengan kebutuhan peserta) dengan kriteria kurang ( 2 peserta).
\end{abstract}

Kata Kunci: Hama dan Penyakit, Pestisida sintetik, Residu pestisida, Dampak negatif.

\section{PENDAHULUAN}

Latar Belakang

Analisis Situasi

A. Kondisi Mitra

Koka adalah sebuah Desa di wilayah Kecamatan Tombulu, Kabupaten Minahasa, Sulawesi Utara, Indonesia (Anonim a, 2019). Kecamatan Tombulu yang keseluruhannya 8.525 ha $\left(85,25 \mathrm{~km}^{2}\right)$, dibagi menjadi delapan Desa (Anonim b, 2019). Kecamatan ini terbentuk sebagai hasil pemekaran dari 6 desa yang mulanya berada di Kecamatan Pineleng dan 2 desa dari Kecamatan Airmadidi. Letaknya pada ketinggian 200-500 m dpl. Kondisi tanah di kecamatan ini sebagian datar dan sisanya berbukit-bukit. Curah hujan rata-rata per tahunnya adalah 2.000-2.500 mm (Anonim a, 2019).

Lahan pertanian di kabupaten Minahasa cukup strategis yaitu mencapai 75.000 Ha. Luas lahan sawah 5.500 Ha (Anonim c, 2019). Lahan 
di Kecamatan Tombulu digunakan untuk pemukiman (4397 ha), sawah (99 ha), perladangan (3.797 ha), alang-alang (197 ha), dan hutan lindung (35 ha) (Anonim a, 2019).

Besarnya luas pertanian dan banyaknya petani di Desa Koka Kecamatan Tombulu tersebut memungkinkan adanya penggunaan pestisida dalam rangka mengendalikan hama dan penyakit tumbuhan yang dewasa ini kerusakan yang ditimbulkan oleh hama dan penyakit tumbuhan dilahan-lahan pertanian sudah menjadi masalah yang serius di dunia pertanian. Berbagai upaya telah dilakukan untuk mengendalikan hama dan penyakit ini baik dengan cara tradisional maupun dengan cara modern yaitu penggunaan pestisida. Menurut Pattiselanno (2001) maka manusia sejak dahulu berusaha untuk mengurangi/menekan laju kerusakannya dengan menggunakan berbagai cara, baik yang bersifat tradisional maupun yang sudah modern yaitu pestisida. Demikian juga yang dilakukan banyak orang khususnya petani di Desa Koka, mereka berusaha menekan ataupun mengurangi tingkat kerusakannya dengan pestisida.

Sampai saat ini kerusakan yang ditimbulkan oleh hama dan penyakit di lahanlahan pertanian sudah menjadi masalah yang serius didunia pertanian. Pada tahun permulaan program intensifikasi pangan, masalah hama dan penyakit diusahakan dengan penanganan secara kimiawi yakni menggunakan pestisida. Dibandingkan dengan teknik-teknik pengendalian hama dan penyakit lainnya, penggunaan pestisida oleh sebagian besar petani dianggap lebih efektif, penggunaannya lebih praktis, dan mendatangkan keuntungan ekonomi yang besar (Untung, 2006). Berbagai jenis pestisida telah digunakan sejak senyawa ini dikenal sebagai senjata ampuh untuk membasmi hama dan penyakit tanaman (Noya, 2004). Sejak diperkenalkan ke dalam dunia pertanian, pestisida (Herbisida, Fungisida, Insektisida, dll) telah menyebabkan produksi pertanian tergantung pada keandalannya selain pada penggunaan pupuk sintetik. Ketergantungan ini juga diperkuat dengan anggapan masyarakat khususnya petani bahwa tanpa menggunakan pestisida panen tidak menghasilkan apa-apa atau gagal sehingga pestisida menjadi "primadona" bagi petani.

Survei yang dilakukan di Sulawesi Utara tahun 1990 menunjukkan bahwa hampir semua petani menggunakan pestisida untuk pengendalian hama dan penyakit pertanian (Sembel, 2010). Disamping dapat membantu manusia dalam usaha mengatasi gangguan hama dan penyakit, ternyata penerapan pestisida memberi pengaruh yang besar terhadap organisme dan lingkungan lain yang bukan sasaran (Murty, 1986 dalam Lasut dkk, 2001). Tindakan pengendalian kimia yang berlebihan dan terus menerus dapat menimbulkan dampak negatif yang merugikan antara lain terjadinya pencemaran lingkungan, terbunuhnya musuhmusuh alami, terjadinya resistensi dan resurgensi hama serta timbulnya residu pada komoditi hasil pertanian tersebut dan berbahaya bagi manusia (Kardinan, 2001).

Mengingat kebutuhan dan kegunaan pestisida maka telah banyak produk pestisida yang beredar di masyarakat khususnya petani. Masing-masing jenis pestisida tersebut memiliki fungsi dan daya racun yang berbeda-beda. Disamping dapat membantu manusia dalam usaha mengatasi gangguan hama dan penyakit tumbuhan, ternyata penerapan pestisida memberi pengaruh yang besar terhadap organisme dan lingkungan lain yang bukan sasaran. Sebagian besar pestisida merupakan bahan kimia yang bersifat racun keras, tidak saja bersifat racun pada hama dan penyakit tumbuhan yang hendak dikendalikan tetapi juga berdampak negatif terhadap lingkungan dan kesehatan manusia. Manusia sebagai tingkat trofik tertinggi dalam rantai makanan tidak luput dari efek buruk penggunaan pestisida baik secara langsung maupun tidak langsung.

Fenomena diatas menunjukkan betapa besarnya ketergantungan petani terhadap pestisida dan betapa besar resiko yang dihadapi petani dalam menggunakan pestisida. Keracunan pestisida dapat terjadi di kalangan petani di Desa Koka Kecamatan Tombulu diakibatkan karena cara penggunaannya yang sembarangan dan kurangnya pemahaman terhadap efek buruk yang ditimbulkannya. Petani dalam hal ini memiliki kedudukan ganda yaitu sebagai pelaku dan 
pengetahuan mereka tentang dampak negatif dari penggunaan pestisida terhadap lingkungan dan kesehatan manusia.

Oleh karena itu bersama mitra akan dilaksanakan kegiatan untuk mengatasi kelemahan/ permasalahan yang dihadapi Mitra, dalam penggunaan pestisida secara terkendali untuk mengurangi tingkat keracunan yang diakibatkannya.

dirangkul dalam kegiatan ini adalah: Para Petani yang mempunyai potensi dalam menggerakkan perekonomian keluarga yang bisa memiliki bekal pengetahuan dalam penggunaan pestisida secara terkendali untuk mengurangi tingkat keracunan yang diakibatkannya dalam rangka menanggulangi hama dan penyakit tumbuhan serta meningkatkan produksi pertanian kearah yang lebih baik lagi.

Selama ini kelemahan umum yang dijumpai di kalangan petani dalam meningkatkan produksi pertanian dan dalam menanggulangi hama dan penyakit tumbuhan adalah kurangnya pengetahuan mereka tentang dampak dari penggunaan pestisida bagi lingkungan dan manusia terutama bagi kesehatan mereka sendiri. Oleh karena itu diperlukan adanya penyuluhan dan pelatihan penggunaan pestisida yang baik dan benar untuk mengurangi tingkat keracunan yang diakibatkannya.

\section{B. Peran Mitra dalam Lingkungan}

Wanita Kaum Ibu (WKI) yang ada di Desa Koka merupakan kelompok masyarakat yang memiliki kegiatan yang paling banyak di Desa Koka sehingga bisa mempengaruhi dan meningkatkan jumlah pendapatan ekonomi keluarga dan masyarakat yang ada di Desa Koka, dimana kegiatan-kegiatan WKI ini dapat menggerakkan perputaran perekonomian Desa Koka, Kecamatan Tombulu, Kabupaten Minahasa.

\section{Permasalahan Mitra}

Salah satu pilar keberhasilan petanipetani Desa Koka Kecamatan Tombulu dalam meningkatkan perekonomian keluarga dan masyarakat adalah peningkatan produksi pertanian dan dalam usaha mengatasi hama dan penyakit tumbuhan secara ramah lingkungan. Kelemahan yang dialami oleh petani-petani Desa Koka Kecamatan Tombulu yaitu kurangnya

\section{Tujuan dan Manfaat Penelitian}

Sesuai dengan rencana kegiatan, maka luaran yang dihasilkan atau ditargetkan dalam kegiatan penelitian pada masyarakat ini adalah :

Peningkatan pengetahuan dan ketrampilan petani dalam penggunaan pestisida sintetis secara terkendali untuk mengurangi tingkat keracunan yang diakibatkannya dan peningkatan kesadaran lingkungan hidup bagi masyarakat di Desa Koka Kecamatan Tombulu Kabupaten Minahasa dari dampak samping yang ditimbulkan oleh pestisida bagi lingkungan dan kesehatan manusia.

\section{METODE PENELITIAN}

\section{Lokasi Penelitian}

Kegiatan PKM ini dilaksanakan di Gedung Gereja GMIM Betlehem Desa Koka Kecamatan Tombulu Kabupaten Minahasa.

\section{Metode yang digunakan :}

Untuk mengatasi permasalahan Wanita Kaum Ibu (WKI) dalam kurangnya pengetahuan tentang bahaya pestisida sintetik dan dampak yang ditimbulkannya bagi lingkungan dan manusia, maka perlu dilakukan penyuluhan dan pelatihan tentang bahaya pestisida sintetik yang meliputi kegiatan:

1. Pemberian teori/ceramah, meliputi:

a. Tinjauan umum/pengertian pestisida.

b. Bahaya/efek samping pestisida terhadap manusia.

c. Mekanisme toksisitas pestisida. 
dilakukan pengukuran terhadap perubahan tersebut. Perubahan diukur dari perbandingan antara nilai pretest sebelum kegiatan berlangsung dan nilai postest setelah kegiatan berlangsung. Ada 10 pertanyaan yang diberikan dalam bentuk soal pilihan ganda dalam waktu 15 menit dengan jumlah peserta 37 orang.

Kegiatan pretest dan postest dilakukan b. Pengaturan Cara Aplikasi Pestisida

- Waktu aplikasi

- Dosis aplikasi

- Sasaran Aplikasi

- Jangka Waktu Sebelum Panen

- Tidak menggunakan bahan perekat (Sticker)

- Alat dan Teknik Aplikasi yang tepat

- Penggunaan Fumigan (pestisida yang mudah menguap)

c. Pengujian residu pestisida

Meliputi tahap-tahap:

- Pengambilan contoh/sampel

- Pewadahan

- Pengiriman

- Penyimpanan

- Analisis di laboratorium

d. Pedoman Pencegahan Keracunan Pestisida

- Membeli pestisida

- Mengangkut pestisida

- Menyimpan pestisida

- Menyiapkan pestisida

- Menyemprotkan pestisida

- Selesai menyemprot

- Penyimpanan kaleng pestisida

e. Penggunaan Alat-Alat Penyemprot

Pestisida

- Cara pakai alat penyemprotan

- Penggunaan alat pelindung diri

\section{HASIL DAN PEMBAHASAN}

dengan tujuan untuk mengetahui pengetahuan dan ketrampilan peserta dalam memahami caracara penggunaan pestisida sintetik dan bahayanya terhadap lingkungan dan kesehatan manusia. Selain itu pula dengan kegiatan ini maka akan ada peningkatan pemahaman peserta akan materi dan peningkatan kesadaran lingkungan hidup bagi masyarakat khususnya petani di Desa Koka Kecamatan Tombulu Kabupaten Minahasa dari dampak samping yang ditimbulkan oleh pestisida sintetik tersebut. Soal-soal pretest dan postest berdasarkan materi yang diberikan yaitu antara lain: tinjauan umum/pengertian pestisida, bahaya/efek samping pestisida terhadap lingkungan dan manusia, mekanisme toksisitas pestisida sintetik, tinjauan umum perilaku petani dalam menggunakan pestisida dan penggunaan pestisida yang baik dan benar.

Dari 10 soal yang diberikan pada kegiatan pretest ternyata pemahaman peserta akan bahaya pestisida sintetik masih kurang, ini ditandai dengan tidak adanya peserta yang memiliki nilai di atas 50. Prosentasi nilai tertinggi hanyalah pada pada interval 0-10 dengan 17 peserta $(45,95 \%)$ dan diikuti oleh interval nilai 11-20 dengan 10 orang $(27,03 \%)$ (Tabel 1). Dari hasil pretest ini menggambarkan bahwa peserta belum memahami akan bahaya penggunaan pestisida sintetik bagi kehidupan mereka.

Tabel 1. Hasil Test Awal (Pretest)

\section{Hasil Pelaksanaan Kegiatan PKM}

1. Pelaksanaan tes awal (pretest)

Untuk menghasilkan suatu perubahan paradigma (pola pikir) dan peningkatan pengetahuan serta ketrampilan mitra tentang bahaya pestisida sintetik dan dampak yang ditimbulkannya bagi lingkungan dan kesehatan manusia maka melalui kegiatan PKM ini 


\section{Pelaksanaan postest (tes akhir)}

Selain nilai pretest yang diukur untuk melihat keberhasilan dari kegiatan PKM ini maka nilai postest juga diukur yang metode pengukurannya sama dengan pretest, soanya sebanyak 10 dalam bentuk pilihan berganda, dengan waktu yang sama pula selama 15 menit. Jumlah peserta yang mengikuti tes ini sama banyaknya yaitu 37 peserta. Bentuk Soal juga sama berdasarkan materi test dalam proses pembelajaran. Dari kegiatan postest ini maka diperoleh hasil yang sangat berbeda, dimana terjadi peningkatan pemahaman dan ketrampilan peserta (Tabel 2).

Pemahaman peserta akan materi meningkat pesat dibandingkan dengan pada saat sebelum diberikan sosialisasi dan pelatihan, hal ini terlihat dari jumlah peserta yang mendapatkan nilai di atas 50 bahkanpun sampai ada yang mendapatkan nilai rata-rata tertinggi di antara interval nilai 91-100 walaupun hanya 1 orang peserta $(2,71 \%)$. Peserta terbanyak dengan nilai prosentase $45,94 \%$ sebanyak 17 orang terdapat pada interval nilai 51-60 (Tabel 2).

Tabel 2. Hasil Test Akhir (Postest)

\begin{tabular}{|c|c|c|c|}
\hline No & $\begin{array}{c}\text { Interval } \\
\text { Nilai }\end{array}$ & $\begin{array}{c}\text { Jumlah } \\
\text { (Orang) }\end{array}$ & $\%$ \\
\hline 1 & $0-10$ & 0 & 0,00 \\
\hline 2 & $11-20$ & 0 & 00,00 \\
\hline 3 & $21-30$ & 0 & 00,00 \\
\hline 4 & $31-40$ & 0 & 00,00 \\
\hline 5 & $41-50$ & 3 & 08,11 \\
\hline 6 & $51-60$ & 17 & 445,94 \\
\hline 7 & $61-70$ & 10 & 27,02 \\
\hline 8 & $71-80$ & 4 & 10,81 \\
\hline 9 & $81-90$ & 2 & 05,41 \\
\hline 10 & $91-100$ & 1 & 2,71 \\
\hline \multicolumn{2}{|c|}{ Jumlah } & 37 & 100,00 \\
\hline
\end{tabular}

Dari Tabel 1 dan 2 di atas sangat jelas terlihat perbedaan pemahaman peserta akan materi yang diberikan pemandu. Perbandingan nilai pretest

\begin{tabular}{|c|c|c|c|}
\hline No & $\begin{array}{c}\text { Interval } \\
\text { Nilai }\end{array}$ & $\begin{array}{c}\text { Jumlah } \\
\text { (Orang) }\end{array}$ & $\%$ \\
\hline 1 & $0-10$ & 17 & 45,95 \\
\hline 2 & $11-20$ & 10 & 27,03 \\
\hline 3 & $21-30$ & 3 & 08,11 \\
\hline 4 & $31-40$ & 2 & 05,40 \\
\hline 5 & $41-50$ & 5 & 13,51 \\
\hline 6 & $51-60$ & 0 & 00,00 \\
\hline 7 & $61-70$ & 0 & 0,00 \\
\hline 8 & $71-80$ & 0 & 0,00 \\
\hline 9 & $81-90$ & 0 & 0,00 \\
\hline 10 & $91-100$ & 0 & 0,00 \\
\hline \multicolumn{2}{|c|}{ Jumlah } & 37 & 100,00 \\
\hline
\end{tabular}

dan postest secara keseluruhan disajikan pada Gambar 1. Dari gambar ini terlihat terjadi peningkatan pemahaman peserta dengan jumlah prosentasi nilai peningkatan sebesar 91.89\%. Peningkatan ini terjadi karena peserta semangat, antusias, dan ada kemauan dan rasa ingin tahu yang besar dalam mengikuti materi yang diberikan sehingga pengetahuan dan pemahaman mereka meningkat pula.

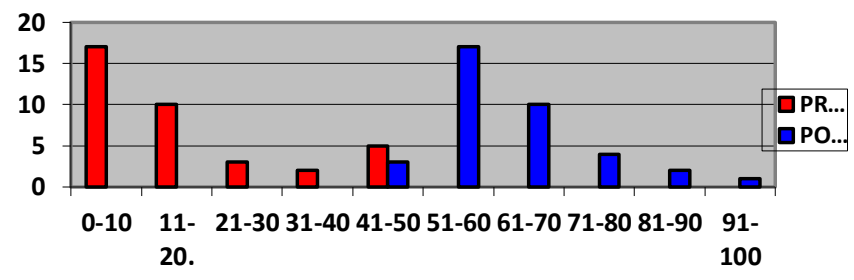

Gambar 1. Perbandingan Nilai Pretest Dan Postest

\section{Praktek Penggunaan Alat Penyemprot Pestisida dan Cara Aplikasi Pestisida}

Materi yang disajikan pada kegiatan praktek ini meliputi cara pemilihan pestisida, pengaturan cara aplikasi pestisida, pengujian residu pestisida, pedoman pencegahan keracunan pestisida, dan alat-alat penyemprot pestisida. Metode yang digunakan yaitu memperagakan cara-cara mempergunakan pestisida dan alat-alat penyemprot pestisida. 


\begin{tabular}{|c|c|c|c|c|c|}
\hline \multirow[b]{2}{*}{$\frac{\breve{d}}{\frac{\mathscr{2}}{\Delta}}$} & \multicolumn{5}{|c|}{ Total Kriteria } \\
\hline & $\begin{array}{c}\text { Sangat } \\
\text { Kurang }\end{array}$ & Kurang & Sedang & Baik & $\begin{array}{c}\text { Sangat } \\
\text { Baik }\end{array}$ \\
\hline $\mathrm{A}$ & 0 & 0 & 9 & 7 & 21 \\
\hline $\mathrm{B}$ & 0 & 2 & 7 & 9 & 20 \\
\hline $\mathrm{C}$ & 0 & 5 & 7 & 9 & 25 \\
\hline $\mathrm{D}$ & 0 & 7 & 9 & 10 & 11 \\
\hline$E$ & 0 & 3 & 9 & 7 & 18 \\
\hline
\end{tabular}

Setelah selesai praktek, maka kemampuan peserta dalam menyerap dan memahami materi praktek diukur dengan pengisian lembar evaluasi topik belajar. Oleh sebab itu setiap peserta mengisi lembar evaluasi topik belajar sesuai dengan kemampuan mereka. Ada 5 aspek yang akan dinilai oleh peserta sesuai dengan 5 kriteria (sangat kurang, kurang, sedang, baik, dan sangat baik).

Hasil pemeriksaan terhadap pengisian evaluasi topik belajar dari peserta menunjukkan bahwa kriteria tertinggi pada aspek ke 3 (motivasi peserta menindaklanjuti semua petunjuk sesuai pelatihan ) dengan kriteria sangat baik (25 peserta), sedangkan kriteria terendah pada aspek ke 2 (kesesuian materi dengan kebutuhan peserta) dengan kriteria kurang (2 peserta). Peserta memiliki motivasi yang tinggi ditandai juga dengan keinginan mereka berkomunikasi dengan pemandu tentang materi ini dan apa yang akan mereka lakukan dalam menindaklanjuti kegitan ini di lapngan nantinya, hal ini tergambar dari keingintahuan mereka akan materi ini. Dalam praktek kali ini, kriteria sangat kurang tidak ada peserta yang memilih. Kemampuan peserta dalam memahami materi praktek juga tinggi nilainya pada kriteria sangat baik (21 orang), hal ini di lihat dari keaktifan dan kreativitas peserta selama mengikuti praktek. Nilai keseluruhan kriteria evaluasi topik belajar disajikan pada Tabel 3.
Tabel 3. Hasil Rekapan Evaluasi Topik Belajar (Praktek)

Dimana:

A. Pemahaman akan materi

B. Kesesuaian materi praktek dengan kebutuhan peserta

C. Motivasi peserta

D. Kemampuan mengkomunikasikan materi kepada orang lain

E. Keinginan berkomunikasi dengan pemateri

Selain peserta diberikan praktek cara penggunaan pestisida dan alat penyemprot pestisida, peserta juga diberikan pedoman tentang bagaimana cara pencegahan terhadap keracunan pestisida seperti halnya ketika membeli pestisida, mengangkut pestisida, menyimpan pestisida, menyiapkan pestisida, menyemprotkan pestisida, selesai menyemprot pestisida, dan penyimpanan kaleng pestisida. Dari praktek pencegahan keracunan pestisida ini maka banyak pertanyaan yang muncul dari peserta, dikarenakan banyak yang belum tahu akan bahayanya residu pestisida terhadap kehidupan mahluk hidup.

\section{KESIMPULAN DAN SARAN}

Terjadi peningkatan pemahaman peserta akan materi sosialisasi dan pelatihan bahaya penggunaan pestisida sintetik pada saat sebelum kegiatan PKM dilaksanakan dan sesudah kegiatan dilaksanakan ditandai dengan jumlah prosentasi nilai pretest pada interval nilai 51-100 sebesar $0,00 \%$ (tidak ada peserta) terjadi peningkatan pada postest sebesar 91.89\% (34 orang). Pada pretest tidak ada peserta yang mendapatkan nilai tertinggi pada interval nilai 91-100 $(0,00 \%)$ tetapi pada postest terdapat 1 orang dengan prosentase sebesar $2,71 \%$. Hasil praktek menunjukkan bahwa kriteria tertinggi pada aspek ke 3 (motivasi peserta menindaklanjuti semua petunjuk sesuai pelatihan ) dengan kriteria sangat baik (25 peserta), sedangkan kriteria terendah pada aspek ke 2 
4298, Volume 13 Nomor 3A, November $2017: 303-312$.

(kesesuian materi dengan kebutuhan peserta) dengan kriteria kurang (2 peserta).

\section{Saran}

Sebaiknya pada tahapan selanjutnya kegiatan PKM seperti ini bisa dilaksanakan pada tingkatan anak-anak, remaja, dan pemuda yang ada di Desa Koka, Kecamatan Tombulu, Kabupaten Minahasa, karena mengingat bahaya pestisida sintetik bagi lingkungan dan kesehatan manusia harus disosialisasikan sejak dini.

\section{UCAPAN TERIMAKASIH}

Dana yang membiayai kegiatan PKM ini berasal dari dana PNBP Unsrat tahun anggaran 2019. Oleh sebab itu pada kesempatan ini ucapan terima kasih disampaikan kepada Pimpinan Universitas Sam Ratulangi Manado dan Pimpinan LPPM Unsrat Manado yang telah mendanai kegiatan ini.

\section{DAFTAR PUSTAKA}

Anonim a, 2019. Koka, Tombulu, Minahasa. Wikipedia.

https://id.wikipedia.org/wiki/Koka, To mbulu,_Minahasa <01/03/2019>.

Anonim b, 2019. Tombulu, Minahasa. Wikipedia.

https://id.wikipedia.org/wiki/Tombulu, Minahasa $<01 / 03 / 2019>$.

Anonim c, 2019. Potensi Lahan Pertanian di Minahasa Masih Strategis. Klik Net News.

http://www.kliknews.net/2019/02/09/la han-pertanian-di-minahasa-masihstrategis/ <01/03/2019>.

Karamoy Reinal Ferdinan, Melsje Y. Memah, dan Grace A. J. Rumagit. 2017. Penerapan Fungsi Manajemen Dalam Kelompok Tani Cempaka Di Kelurahan Meras Kecamatan Bunaken Kota Manado. Artikel. AgriSosioEkonomi Unsrat, ISSN 1907- https://ejournal.unsrat.ac.id/index.php/j isep/article/download/18398/1792 (Diakses tanggal 2 Maret 2018).

Kardinan, A. 2001. Pestisida Nabati, Ramuan dan Aplikasi. Penebar Swadaya. Jakarta.

Lasut, M.T., B. Polii dan V.A. Kumurur. 2001. Komparasi Tingkat Toksisitas Beberapa Pestisida (Endosulfan, Fentoat, BPMC, Glifosat, Sulfosat, 2,4 D) Dengan Menggunakan Ikan Bandeng (Chanos chanos Forsk). EKOTON. Jurnal Lingkungan Hidup dan Sumberdaya Alam. 1 (1) : 1-6

Noya, A.I. 2004. Residu Insektisida Profenofos Pada Sayuran Kubis Dan Tanah Andosol Rurukan Kecamatan Tomohon. Tesis. Program Pasca Sarjana Universitas Samratulangi Manado

Pattiselanno, A.E. 2001. Analisis Sikap dan Perilaku Terhadap Sasi Pada Masyarakat Pulau Saparua Kabupaten Maluku Tengah. Eugenia. 7(4) : 282-288

Pontoh, S.C. 2014. Perbandingan Pendapatan Petani Padi Sawah Peserta Dan Bukan Peserta Pasar Lelang Komoditi Agro (PLKA) Di Kelurahan Kiniar Kecamatan Tondano Timur. Jurnal. download.portalgaruda.org/article.ph p?...PERBANDI.. (Diakses pada tanggal 27 November 2015).

Sembel, D.T. 2010. Pengendalian Hayati. Hama-hama Serangga Tropis dan Gulma. Penerbit ANDI. Yogyakarta.

Thio Trifena L. M, Christy N. Mintjelungan, dan Bernat S. P. Hutagalung. 2018. Pola Kehilangan Gigi Dan Kebutuhan 
Perawatan Gigi Tiruan Sebagian

Lepasan Dikelurahan Meras

Kecamatan Bunaken. Artikel.

download.portalgaruda.org/article.php

?...POLA\%20KEHILANGAN\%20GI

GI\%20DA... (Diakses tanggal 2 Maret 2018).

Untung, K. 2006. Pengantar Pengelolaan

Hama Terpadu (edisi kedua).

Penerbit Gadjah Mada University

Press. Yogyakarta. 